character, as, for example, the series of papers in the "Records of the Indian Museum" for April. Jf any of these are to be chosen for special mention it must be the profusely illustrated "Contribution to a Knowledge of the Terrestrial Isopods of India," by Mr. W. E. Collinge, describing a collection of species new to science from the Madras Province of Southern India.

The Journal of the Federated Malay States Museums for March contains a valuable paper on the zoology of Koh Samui and Koh Pennan by Messrs. H. C. Robinson and C. Boden Kloss, and another on the plants therefrom by Prof. H. N. Ridley; while the April number contains a most interesting summary of Malay filigree work by Mr. I. H. N. Evans.

The thirteenth report of the Sarawak Museum contains a complete list of all the mosquitoes known from Borneo. The material for this was collected by the curator, Mr. J. C. Moulton-now on active service in France-and determined by Mr. F. W. Edwards, of the British Museum.

The Report of the South African Museum contains a brief summary of the acquisitions of the Geological Department, some of which are of considerable importance, as, for example, the remains of a small dinosaur from Bushmanland, apparently allied to the Cretaceous dinosaurs, and which throw light on the age of the old land surface in the north-west of the Cape Province.

The Records of the Albany Museum for May contains seven papers, one of which, on the fleas infesting various wild South African mammals, may prove of more importance than would appear at first sight.

All these institutions appear to be in a flourishing condition, but this is evidently far from true of the Rhodesia Mu'seum, Bulawayo, which, in its thirteenth annual report, complains bitterly of the lack of funds. So seriously has its income fallen off that it has been necessary not only to reduce its staff, but to suspend even work necessary to ensure the well-being of the collections. We trust that better days are in store for the Albany Museum.

\section{ENTOMOLOGICAL WORK IN CANADA.}

$R$ ECENT publications of the Entomological Branch R of the Canadian Department of Agriculture illustrate the wide field of the activities of Dr. Gordon Hewitt and his staff and the advances they are making in our knowledge of the control of insects.

In the Canadian Entomologist for March, I915, Dr. Hewitt discusses the hibernation of the house-fly in a paper that is of very great topical value at the moment in this country; he finds that the maggots pupate at depths up to $2 \mathrm{ft}$. below and away from a manure heap, where this is situated on sandy loam; he finds also that the flies emerge from this situation. Discussing the hibernation of the insect, he reiterates his belief that it is as the adult that they live over the winter in northern latitudes.

In the Transactions of the Royal Society of Canada for September, 1914, Dr. Hewitt describes observations on the feeding of the stable-fly, Stomoxys calcitrans, which will be of value to those seeking to fix the rôle this insect plays in the dissemination of disease, notably of infantile paralysis.

A circular of the Department of Agriculture contains the instructions to importers of trees, plants, and other nursery stock into Canada; it explains clearly and simply what the importer has to do, and reprints the text of the Act. Another circular deals with the control of locusts in eastern Canada; the author, A. Gibson, uses the term locust for grasshopper, whereas No. 2387 , VOL. 95] it is better restricted to the migratory grasshoppers; but the circular is for popular use, and the term is probably so used in eastern Canada.

The most interesting point is the value of adding lemon juice to the poisoned bait for killing the insects; the method originated in Kansas, and works well in Canada.

In Bulletin No. 9 Mr. Gibson deals with the Army worm Cirphis unipuncta, an insect which caused a loss of 50 ,odol. in Ontario alone. He emphasises the great importance of co-operation among farmers in dealing with outbreaks promptly and thoroughly by means of trenching, poisoning, and rolling. It is possible that something better could be done with moth trapping on the "Andres Maire" system, which has proved successful elsewhere. The bulletin is a thoroughly practical, useful piece of work, and the Department evidently has the confidence of the farming community in Canada.

H. M. L.

\section{THE SUPPLY OF OPTICAL GLASS.}

$T$ HE subject of the supply of optical glass and the needs and opportunities-offered to the optical trade, by war and after-war conditions, still continues to attract the attention which it deserves. On July 16 an important conference was: held at the London Chamber of Commerce between the Court and representatives of the Spectacle Makers' Company and representatives of the chamber and of the trade. The conference was convened by the company, and the chair was taken by the master, Sir J. F. L. Rolleston, M.P. There were also present Lord Southwark, president of the Chamber of Commerce, Viscount Hill, Sir William Hart Dyke, Sir Marcus Samuel, Dr. R. M. Walmsley, and others. The chairman opened the proceedings, and in the course of his speech explained how the debate in the House of Commons on optical matters which was initiated by Sir Philip Magnus on May I9, and in which several well-informed members, including the chairman, were prepared to take part, was interrupted and practically closured by the Prime Minister's very important announcement on "Coalition Government." He also referred to various matters to which we have directed the attention of our readers as they arose.

Lord Southwark, in opening the discussion, referred to the fact that he was not only the president of the chamber, but also a past-master of the Skinners' Company, which is so closely associated with the Northampton Polytechnic Institute and its work. He emphasised the importance of concerted action and the help which the City companies could give, and referred also to the valuable assistance which could be rendered by the chamber. In the discussion which followed, it was understood that the remarks made by trade members should not be reported. Dr. Walmsley; who was called upon to speak early in the debate, explained the points referred to in his letter to the Times of April 28, and indicated the importance of the opportunities which have now arisen for the recapture of those branches of the optical instrument trade which were so heavily handicapped before the war. He pointed out that this was worthy of a very earnest effort, and he referred particularly to the value of the trade in the employment of highly skilled labour, which forms so important an item in the production of complicated optical instruments, such as microscopes, etc. $\mathrm{He}$ also dwelt upon the necessity for training designers and computers. The importance of the spectaclemaking branch of the trade was fully insisted upon, and eventually it was decided, on the motion of Lord 